\title{
LEGIBILITY
}

A major purpose of the Technical Information Center is to provide the broadest dissemination possible of information contained in DOE's Research and Development Reports to business, industry, the academic community, and federal, state and local governments.

Although a small portion of this report is not reproducible, it is being made available to expedite the availability of information on the research discussed herein. 


\title{
HEALTH AND SAFETY RESEARCH DIVISION
}

Waste Management Research and Development Programs (Activity No. AH 100500 0; NEAH001)

\section{RESULTS OF THE RADIOLOGICAL SURVEY AT 105 GARIBALDI AVENUE, LODI, INEW JERSEY (LJ065)}

\author{
R. D. Foley, L. M. Floyd, and R. F. Carrier \\ Date Published - November 1989 \\ Ivvestigation Team \\ R. E. Swaja - Measurement Applications and Development Manager \\ W. D. Cottrell - FUSRAP Project Director \\ R. D. Foley - Field Survey Supervisor \\ Survey Team Members \\ K. S. Dickerson \\ A. K. Klitz \\ R. A. Mathis \\ W. Winton \\ W. H. Shinpaugh* \\ *Stone Associates \\ Work performed by the \\ MEASUREMENT APPLICATIONS AND DEVELOPMENT GROUP \\ Prepared by the
OAK RIDGE NATIONAL LABORATORY
Oak Ridge, Trennemee 37831-6285
operated by
MARTIN MARIETTA ENERGY SYSTEMS, INC
for the \\ U. S. DEPARTMENT OF ENERGY \\ under contrect DE-ACOS-84OR?1400
}




\section{CONTENTS}

LIST OF FIGURES . . . . . . . . . . . . . . . . . . . . v LIST OF TABLES . . . . . . . . . . . . . . . . vii ACKNOWLEDGMENTS . . . . . . . . . . . . ix

ABSTRACT ............................ INTRODUCTION . . . . . . . . . . . . . . . 1 SURVEY METHODS . . . . . . . . . . . . . . . . . . . . . 2

SURVEY RESULTS . . . . . . . . . . . . . . . . . . . . . . 2

Surface Gamma Radiation Levels . . . . . . . . . . . . . 3

Systematic Soil Samples . . . . . . . . . . . . . . . . . . . . . 3

Auger Hole Soil Samples and Gamma Logging . . . . . . . . . . 3

SIGNIFICANCE OF FINDINGS . . . . . . . . . . . . . 3

REFERENCES .................... . . 4 


\section{LIST OF FIGURES}

1 Gamma radiation levels $(\mu \mathrm{R} / \mathrm{h})$ measured on the surface at 105 Garibaldi Avenue, Lodi, New Jersey (LJ065) . . . . . . . . . . 5

2 Diagram showing locations of soil samples taken at 105 Garibaldi Avenue, Lodi, New Jersey (LJ065) . . . . . . . . . . . . 6

3 Gamma profile for auger nole 1 (LJ065A1) at 105 Garibaldi Avenue, Lodi, New Jersey . . . . . . . . . . . . . . . . . 7

4 Gamma profile for auger hole 2 (LJ065A2) at 1J5 Garibaldi Avenue, Lodi, New Jersey . . . . . . . . . . . . . . . . 8 


\section{LIST OF TABLES}

1 Applicable guidelines for protection against radiation . . . . . . . 9

2 Background radiation levels in soil from the northern New Jersey area . . . . . . . . . . . . . . . 9

3 Concentrations of radionuclides in soil at 105 Garibaldi Avenue, Lodi, New Jersey (LJ065) . . . . . . . . . . . . . . . 10 


\section{ACKNOWLEDGMENTS}

Research for this project was sponsored by the Division of Facility and Site Decommissioning Projects, U.S. Department of Energy, under contract DE-ACO584OR21400 with Martin Marietta Energy Systems, Inc. The authors wish to acknowledge the support of J. E Baublitz, Acting Director, Office of Remedial Action and Waste Technology; J. J. Fiore, Director, Division of Facility and Site Decommissioning Projects; and members of their stafis. The authors also appreciate the contributions of J. L. Rich, S. W. Hawthorne, and L. J. Jeffers of the Publications Division; M. S. Uziel of the Environmental Remediation Group; D. A. Roberts and T. R. Stewart of the Measurement Applications and Development Group; and W. H. Shinpaugh of Don Stone Associates for participation in the collection, analyses, editing, and reporting of data for this survey. 


\begin{abstract}
Maywood Chemical Works (MCW) of Maywood, New Jersey, generated process wastes and residues associated with the production and refining of thorium and thorium compounds from monazite ores from 1916 to 1956 . MCW supplied rare earth metals and thorium compounds to the Atomic Energy Commission and various other government agencies from the late 1940 s to the mid-1950s. Area residents used the sandlike waste from this thorium extraction process mixed with tea and cocoa leaves as mulch in their yards. Some of these contaminated wastes were abso eroded from the site into Lodi Brook At the request of the U.S. Department of Energy (DOE), a group from Oak Ridge National Laboratory conducts investigative radiological surveys of properties in the vicinity of MCW to determine whether a property is contaminated with radioactive residues, principally ${ }^{222} \mathrm{Th}$, derived from the MCW site. The survey typically includes direct measurement of gamma radiation levels and soil sampling for radionuclide analyses. The survey of this site, 105 Garibaldi Avenue. Lodi, New Jersey (LJ065), was conducted during 1987.
\end{abstract}

Results of th a survey demonstrated no radionuclide concentrations in excess of the DOE Formerly Utilized Sites Remedial Action Program criteria The radionuclide distributions were not significantly different from normal background levels in the northern New Jersey area. 


\section{RESULTS OF THE RADIOLOGICAL SURVEY AT 105 GARIBALDI AVENUE, LODI, NEW JERSEY (LJ065)*}

\section{INTRODUCTION}

From 1916 to 1956 , piocess wastes and residues associated with the production and refining of thorium and thorium compounds from monazite ores were generated by the Maywocd Chemical Works (MCW), Maywood, New Jersey. During the latter part of this period, MCW supplied rare earth metals and thorium compounds to various government agencies. In the 1940s and 1950s, MCW produced thorium and lithium, under contract, for the Atomic Energy Commission (AEC). These activities ceased in 1956, and, approximately three years later, the 30-acre real estate was purchased by the Stepan Company. The property is located at 100 Hunter Avenue in a highly developed area in Maywood and Rochelle Park, Bergen County, New Jersey.

During the early years of operation, MCW stored wastes and residues in lowlying areas west of the processing facilities. In the early 1930s, these areas were separated frors the rest of the property by the construction of New Jersey State Highway 17. The Stepan property, the interim storage facility, and several vicinity properties have been designated for remedial action by the U.S. Department of Energy (DOE).

The waste produced by the thorium extraction process was a sandlike material containing residual amounts of thorium and its decay products, with smaller quantities of uranium and its decay products. During the years 1928 and 1944 to 1046, area residents used these process wastes mixed with tea and cocoa leaves as mulch in their lawns and gardens. In addition, some of the contaminated wastes were apparently eroded from the site into Lodi Brook and carried downstream.

Lodi Brook is a small stream flowing south from Maywood with its headwaters near the Stepan waste storage site. Approximately $150 \mathrm{ft}$ after passing under State Route 17, the strcaru has been diverted underground through concrete or steel culverts until it merges with the Saddle River in Lodi, New Jersey. Only a small section near Interstate 80 remains uncovered. From the 1940s to the 1970 s when the stream was being diverted underground, its course was altered several times. Some of these changes resulted in the movement of contaminated soil to the surface of a few properties, where it is still in evidence. In other instances, the contaminated soil was covered over or mixed with clean fill, leaving no immediate evidence on the surface. Therefore, properties in question may be drilled in search of former streambed material, even in the absence of surface contamination.

As a result of the Energy and Water Appropriations Act of Fiscal Year 1984, the property discussed in this report and properties is its vicinity contaminated with residues from the former $\mathrm{MCW}$ were included as a decontamination research

\footnotetext{
"The survey was performed by members of the Measurement App" ations and Development Group of the Health and Safety Research Diviaion at Oak Ridge National Laboratory under DOE contract DE-AC05-840R21400.
} 
and development project under the DOE Formerly Utilized Sites Remedial Action Program. As part of this project, DOE is conducting radiological surveys in the vicinity of the site to identify properties contaminated with residues derived from the MCW. The principal radionuclide of concern is thorium-232. The radiological surveys discussed in this report are part of that effort and were conducted, at the request of DOE, by members of the Measurement Applications and Development Group of the Oak Ridge National Lisboratory.

A radiological survey of the private, residential property at 105 Garibaldi Avenue, Lodi, New Jersey, was conducted during 1987. The survey and sampling of the ground surface, as well as the follow-up subsurface investigation, were carried out on June 4 and 5, 1987.

\section{SURVEY METHODS}

The radiological survey of the property included: (1) a gamma scan of the entire property outdoors, (2) collection of surface and subsurface soil samples, and (3) gamma profiles of auger holes. No indoor survey measurements were performed.

Using a portable gamma scintillation meter, ranges of measurements were recorded for areas of the property surface. Systematic soil samples were taken at various locations on the property, irrespective of gamma radiation levels.

To define the extent of possible subsurface soil contamination, auger holes were drilled to depths of approximately $1.8 \mathrm{~m}$. A plastic pipe was placed in each hole, and a $\mathrm{NaI}$ scintillation probe was lowered inside the pipe. The probe was encased in a lead shield with a horizontal row of collimating slits on the side. This collimation aliows measurement of gamma radiation intensities resulting from contamination within small fractions of the hole depth. Measurements were usually made at $15-$ or $30-\mathrm{cm}$ intervals. If the gamma readings in the hole were elevated, a soil sample was scraped from the wall of the auger hole at the point showing the highest gamma radiation level. The auger hole lozgings were used to select locations where further soil sampling would be useful. A split-spoon sampler was used to collect subsurface samples at known depths. In some auger holes, a combination of splitspoon sampling and side-wall scraping was used to collect samples. These survey methods followed the plan outlined in Reference 1. A comprehensive description of the survey methods and instrumentation has been presented in another report. ${ }^{2}$

\section{SURVEY RESULTS}

Applicable federal guidelines are summarized in Table $1 .^{3}$ The normal background radiation levels for the northern New Jersey area are presented in Table 2.4 These data are provided for comparison with survey results presented in this report. All direct measurement results presented in this report are gross readings; background radiation levels have not been subtracted. Similarly, background concentrations have not been subtracted from radionuclide concentrations measured in environmental samples. 


\section{Surface Gamma Radiation Levels}

Gamma radiation levels measured during a gamma scan of the surface of the property are given in Fig. 1. Gamma exposure rates over the major portion of the property ranged from 5 to $9 \mu \mathrm{R} / \mathrm{h}$. The highest gamma levels were found in the backyard and on the northwestern side of the house, ranging from 9 to $11 \mu \mathrm{R} / \mathrm{h}$.

\section{Systematic Soil Samples}

Systematic soil samples were taken from various locations on the property for radionuclide analyses. Locations of these samples (S) are shown in Fig. 2, with results of laboratory anal'ses provided in Table 3. Concentrations of radium and thorium in these samples ringed from 0.57 to $0.75 \mathrm{pCi} / \mathrm{g}$ and 0.75 to $0.93 \mathrm{pCi} / \mathrm{g}$, respectively. Both samples were near or below normal background levels for the northern New Jersey area (Table 2) and were well below DOE guidelines (Table 1).

\section{Auger Hole Soil Samples and Gamma Logging}

Varying thicknesses of subsurface soil were sampled from depths of 15 to $90 \mathrm{~cm}$ in auger holes (A) drilled at two separate locations irdicated in Fig. 2. The results of analyses of these samples are given in Table 3. Concentrations of ${ }^{226} \mathrm{Ra}$ and ${ }^{232} \mathrm{Th}$ in these auger soil samples ranged from 0.39 to 0.53 and 0.57 to $0.66 \mathrm{pCi} / \mathrm{g}$, respectively; all values were below DOE criteria (Table 1 ) for radium and thorium and were well below background (Table 2).

Gamma logging was performed in each of the auger holes to characterize and further define the extent of possible contamination. The logging technique used here is not radionuclide specific. However, logging data, in conjunction with soil analyses data, may be used to estimate regions of elevated radionuclide concentrations in auger holes when compared with background levels for the area. Following a comparison of these data, it appears that any shielded scintillator readings of 1000 counts per minute (cpm) or greater generally indicate the presence of elevated concentrations of ${ }^{226} \mathrm{Ra}$ and/or ${ }^{232} \mathrm{Th}$. Data from the gamma profiles of the logged auger holes are graphically represented in Figs. 3 and 4 . All readings were below $1000 \mathrm{cpm}$.

\section{SIGNIFICANCE OF FINDINGS}

Measurements and results of soil sample analyses taken at 105 Garibaldi Avenue indicate that the property contained no radionuclide concentrations above DOE guideline values. The radionuclide distributions on this property were similar to normal background levels for the northern New Jersey area. 


\section{REFERENCES}

1. W. D. Cottrell, ORNL, to A. J. Whitman, DOE/HQ, correspondence, "Radiological Survey of Private Properties in Lodi, New Jersey" (August 15, 1984).

2. T. E. Myrick, B. A. Berven, W. D. Cottrell, W. A. Goldsmith, and F. F. Haywood, Procedures Manual for the ORNL Radiological Survey Activities (RASA) Program, Oak Ridge National Laboratory, ORNL/TM-8600 (April 1987).

3. U.S. Department of Energy, Guidelines for Residual Radioactive Material at Formerly Utilized Sites Remedial Action Program and Remote Surplus Facilities Management Program Sites (Rev. 2, March 1987).

4. T. E. Myrick, B. A. Berven, and F. F. Haywood, State Background Radiation Levels: Results of Measurements Taken During 19751979,Oak Ridge National Laboratory, ORNL/TM-7343 (November 1981). 


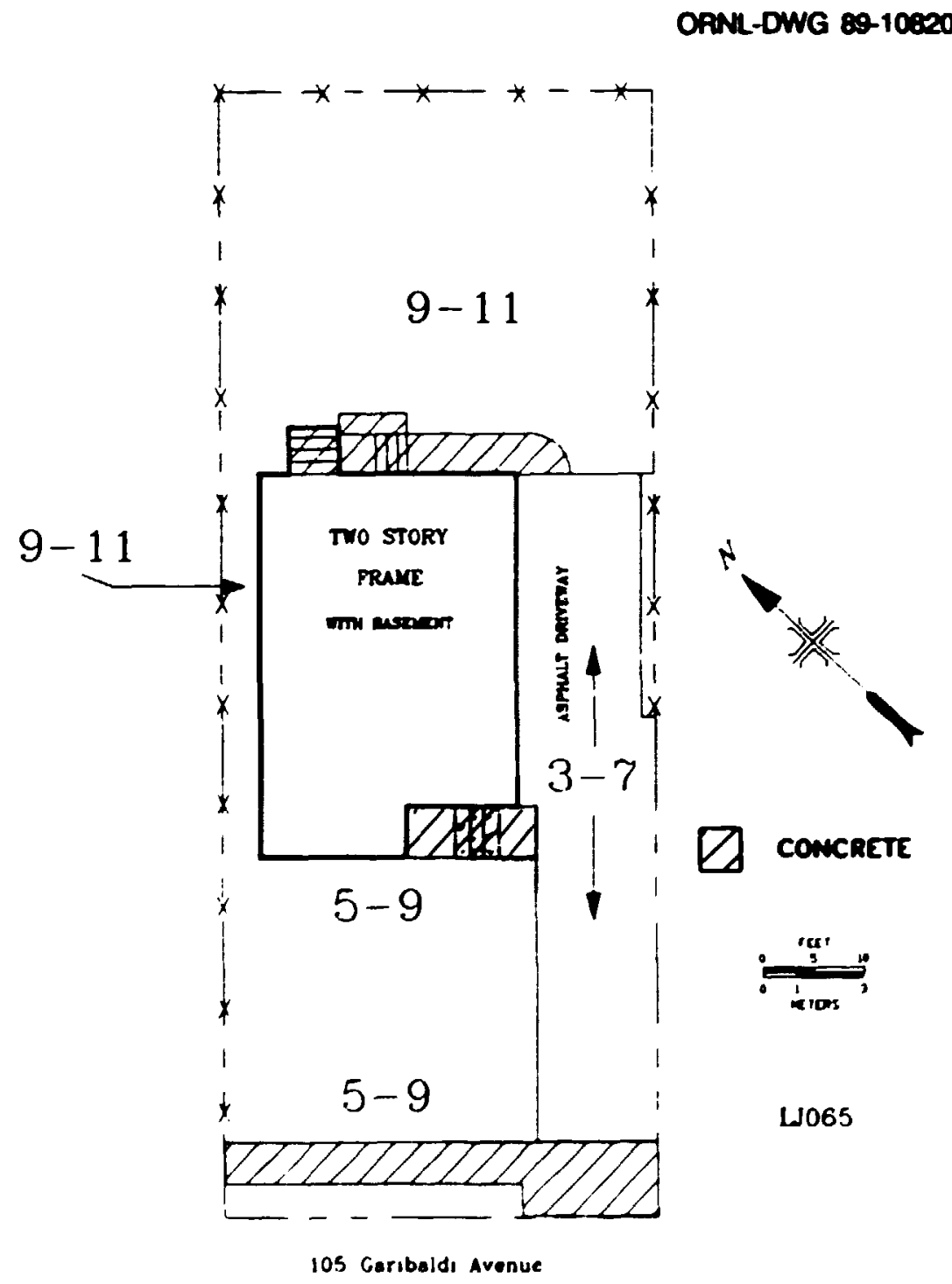

Fig. 1. Gamma radiation levels $(\mu R / h)$ measured on the surface at 105 Garibaldi Avenue, Lodi, New Jeney (LO65). 
ORNL-DWG 89-10821

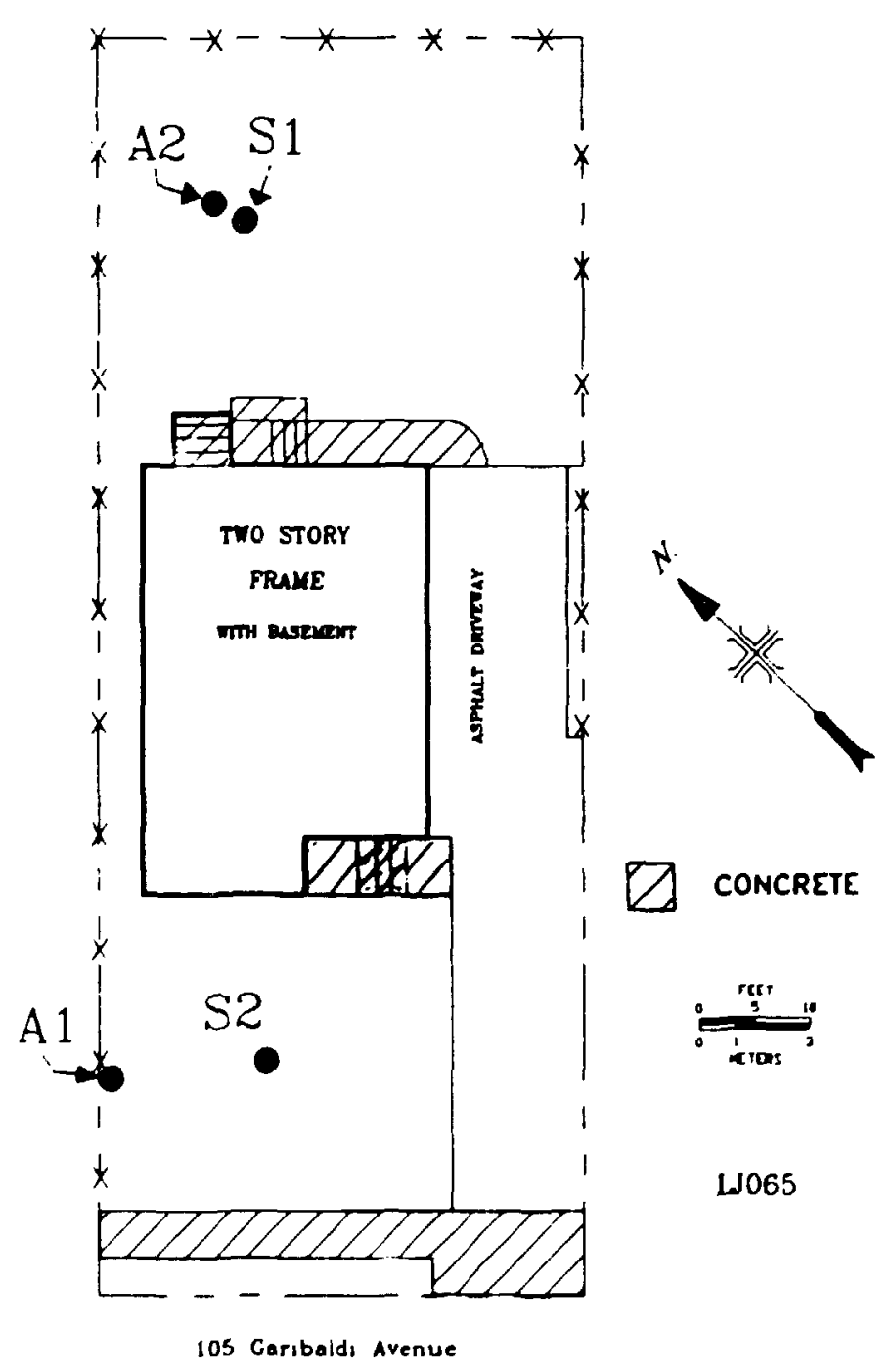

Fig. 2 Diagram sbowing bcations of soil samples taken at 105 Garibaldi Avenue, Lodi, Now Jerrey (uJ065). 
OANL-DWG 89-10822

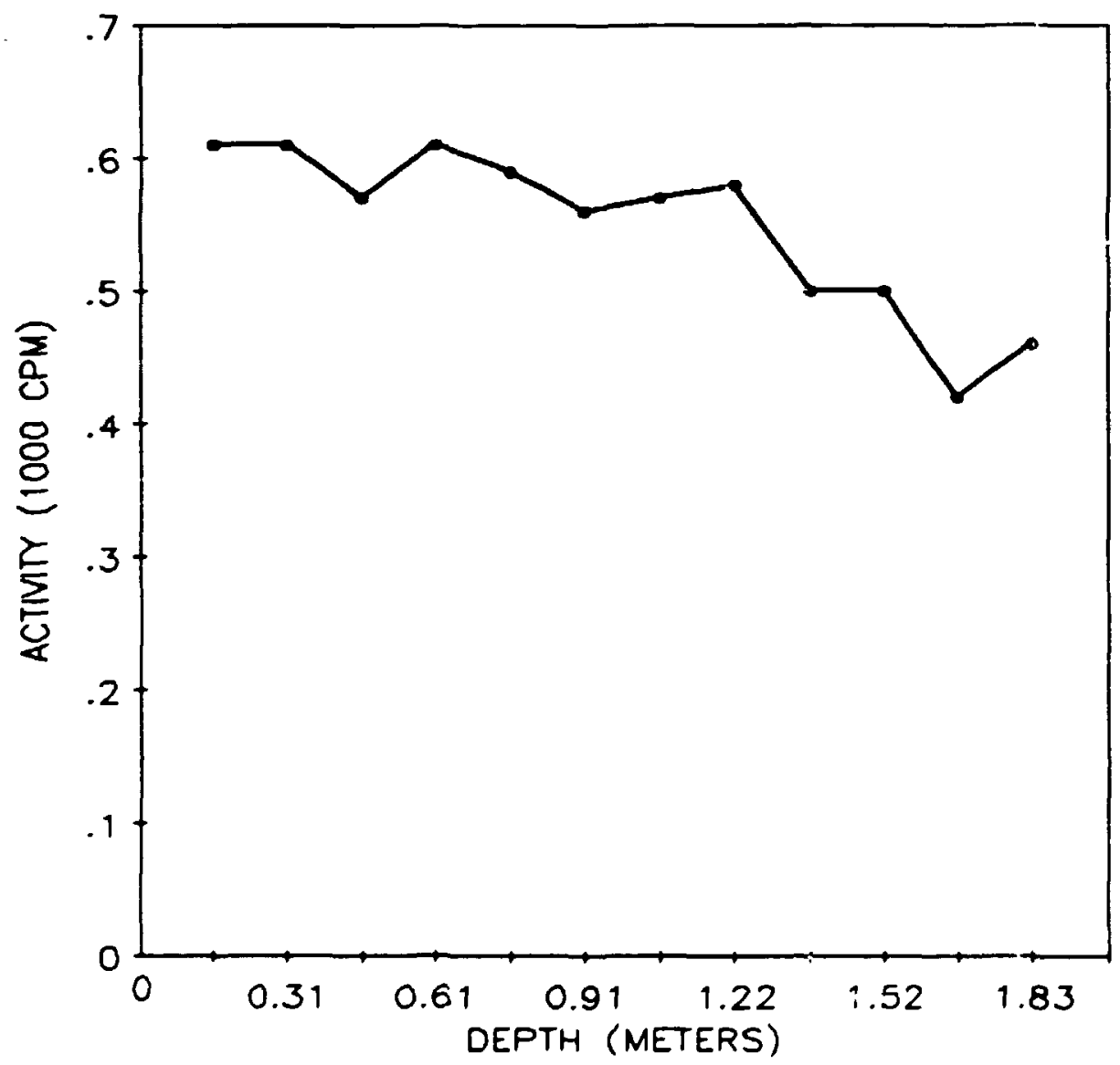

Fig. 3. Gamma profile for auger bole 1 (LJO65A1) at 1.5 Garibaldi Avenue, Lodi, New Jerrey. 
OPINL-DWG 89-10823

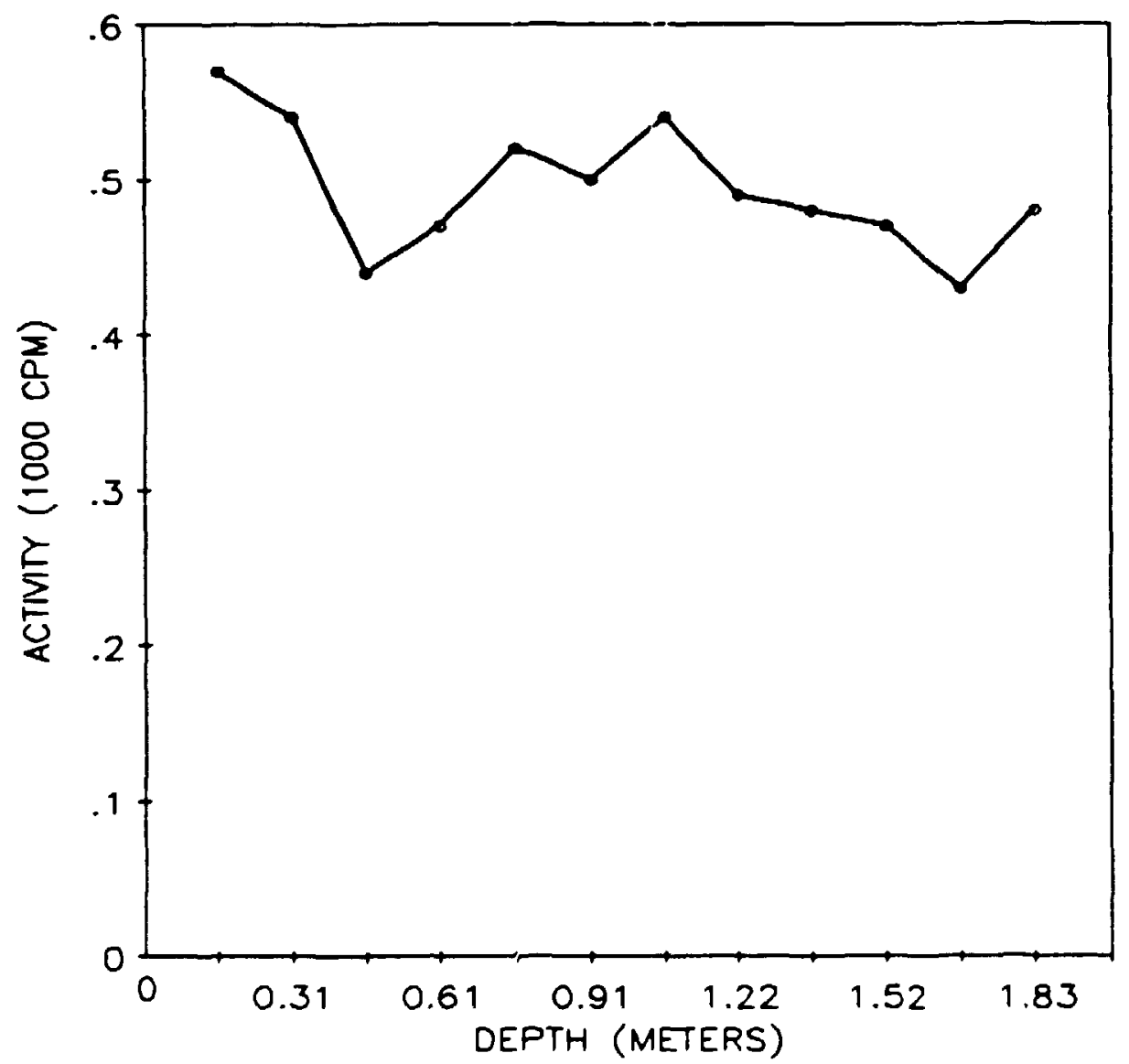

Fig. 4. Gamma profile for auger bole 2 (LO65A2) at 105 Garibaldi Avenue, Lodi, New Jersey. 
Table 1. Applicable guidelines for protection against radiation"

\begin{tabular}{|c|c|c|}
\hline Mode of exposure & Exposure conditions & Guideline value \\
\hline \multirow[t]{2}{*}{$\begin{array}{l}\text { Radionuclide concen- } \\
\text { trations in soil }\end{array}$} & $\begin{array}{l}\text { Maximum permissible con- } \\
\text { centration of the follow- } \\
\text { ing radionuclides in soil } \\
\text { above background levels } \\
\text { averaged over } 100 \mathrm{~m}^{2} \text { area } \\
232 \mathrm{Th} \\
230 \mathrm{Th} \\
228 \mathrm{Ra} \\
200 \mathrm{Ra}\end{array}$ & $\begin{array}{l}5 \mathrm{pCi} / \mathrm{g} \text { averaged over the first } \\
15-\mathrm{cm} \text { of soil below the sur- } \\
\text { face; } 15 \mathrm{pCi} / \mathrm{g} \text { when averaged } \\
\text { over } 15-\mathrm{cm} \text { thick soil layers } \\
\text { more than } 15 \mathrm{~cm} \text { below the } \\
\text { surface }\end{array}$ \\
\hline & 238U & Derived (site specific) \\
\hline
\end{tabular}

Reference 3.

Table 2. Background radiation levels in soil from the northern New Jersey area

\begin{tabular}{lc}
\hline Radionuclide & \multicolumn{1}{c}{ Concentration (pCi/g) } \\
\hline $200 \mathrm{Ra}$ & $0.9^{b}$ \\
$232 \mathrm{Th}$ & $0.9^{b}$ \\
$238 \mathrm{U}$ & $0.9^{b}$ \\
\hline These values represent an average of normal \\
rajionuclide concentrations in this part of the \\
state. Actual values may fluctuate. \\
'Reference 4.
\end{tabular}


Table 3. Concentrations of radionnciides in soil at

105 Garibaldi Arenee, Lodi, New Jersey (LJ065)

\begin{tabular}{lccc}
\hline & \multirow{2}{*}{$\begin{array}{c}\text { Depth } \\
\text { Sample }\end{array}$} & \multicolumn{2}{c}{ Radionuclide concentration $(\mathrm{pCi} / \mathrm{g})$} \\
\cline { 3 - 4 } & & ${ }^{226} \mathrm{Ra}^{b}$ & ${ }^{232} \mathrm{Th}^{b}$ \\
\hline & & Systematic samples \\
S1 & $0-15$ & $0.57 \pm 0.06$ & $0.75 \pm 0.1$ \\
S2 & $0-15$ & $0.75 \pm 0.1$ & $0.93 \pm 0.1$ \\
& & Auger samples & \\
& & $0.39 \pm 0.07$ & $0.65 \pm 0.09$ \\
A1A & $15-30$ & $0.39 \pm 0.08$ & $0.63 \pm 0.1$ \\
A1B & $60-75$ & $0.53 \pm 0.02$ & $0.66 \pm 0.1$ \\
A2A & $30-45$ & $0.46 \pm 0.04$ & $0.57 \pm 0.1$ \\
A2B & $75-90$ &
\end{tabular}

${ }^{a}$ Locations of soil samples are shown on Fig. 2.

${ }^{b}$ Indicated counting error is at the $95 \%$ confidence level $( \pm 2 \sigma)$.

'Systematic samples are taken at locations irrespective of gamma exposure rates.

${ }^{d}$ Auger samples are taken from holes drilled to further define the depth and extent of radioactive material. Holes are drilled where the surface may or may not be contaminated. 